\title{
Welfare reform and recession: past labour market responses to job losses and the potential impact of Employment Support Allowance
}

\author{
Paul Sissons* \\ Institute for Employment Studies
}

\begin{abstract}
The job losses which occurred as a result of deindustrialisation in the 1980s resulted in a large growth in male economic inactivity, and particularly an increased number claiming Invalidity, subsequently Incapacity Benefit (IB). This created high rates of IB claiming which have never been satisfactorily addressed by subsequent policies. In October 2008, Employment and Support Allowance (ESA) was introduced for new claimants to replace Incapacity Benefit. Between 2009 and 2013 those claiming under the old Incapacity Benefit will also be progressively transferred to the new regime. The changes were designed to both reduce on-flows to the benefit, as well as increase off-flows.

The reforms mean that job losses in the present recession will largely feed directly into unemployment, which is likely to remain relatively high for a prolonged period, particularly in old industrial areas where it is currently growing most rapidly and where employment levels are predicted to recover most slowly. This will make it much more difficult to achieve Government targets of significant reductions in the numbers on sickness benefits, as these groups will find it increasingly difficult to compete for jobs with the newly unemployed. It is therefore argued that more thought needs to go into the balance of policy between supply and demand-side interventions in the labour market.
\end{abstract}

Keywords: recession, Employment Support Allowance, Incapacity Benefit, labour markets, unemployment.

\section{Introduction}

From mid 2008 the UK economy entered a period of deep economic recession, with large numbers of job cuts spread across a range of sectors and across the country. The timing of the downturn is significant, coming at a time of fairly wide-ranging and significant welfare reforms. Of particular importance is the replacement of Incapacity Benefit (IB) with Employment Support Allowance (ESA), a change which 
p. 172. Welfare reform and recession: past labour market responses to job losses and the potential impact of Employment Support Allowance

was designed to reduce on-flows to sickness benefits and, in the medium term, also to increase off-flows.

This paper explores what past labour market adjustments to job losses might tell us about the implications of the current downturn in demand for labour. It will also discuss how welfare-to-work reforms of the sickness benefit system might affect this, and how recession will impact on the policy goal of encouraging more people from health-related benefits into employment. The paper focuses primarily on men since they have been disproportionately affected by previous recessions, and the emerging evidence suggests this will be true again this time (ONS, 2009).

The growth of claims for Incapacity Benefit and their subsequent partial decline, as well as the recent trends in claimant unemployment, are examined using the ONS area classification. The classification is a hierarchical structure, grouping local authority areas which share similar population characteristics. There are eight supergroups which divide into 13 groups and 24 sub-groups. This paper uses the groups, since sub-group data was felt to be too unwieldy. The data cover local authorities in Great Britain. The area type groups are:

- Regional Centres

- Centres with Industry

- Thriving London Periphery

- London Suburbs

- London Centre

- London Cosmopolitan

- Prospering Smaller Towns

- New and Growing Towns

- Prospering Southern England

- Coastal and Countryside

- Industrial Hinterlands

- Manufacturing Towns.

All the IB figures quoted in this paper include claimants who by virtue of their limited National Insurance (NI) contributions only qualified for ' $\mathrm{NI}$ credits only' IB. Most individuals in this group also receive means-tested Income Support (IS) (Beatty, et al., 2009). The IB figures also include claimants of Severe Disablement Allowance (SDA), a benefit which was paid to individuals with limited $\mathrm{NI}$ contributions and who were assessed as having a high level of disability. SDA was closed to new claims in 2001 but is still paid to a small number of individuals whose claims pre-date this.

\section{Labour market responses to the loss of industrial jobs}

The huge job losses which occurred as a result of economic restructuring in Britain's industrial communities in the 1980s produced rising unemployment which over the medium-term fed into increasing male economic inactivity, and specifically into increased numbers claiming Invalidity, subsequently Incapacity, Benefits (Turok and Edge, 1999; Beatty and Fothergill, 1996, 1997; Fieldhouse and Hollywood, 
p. 173. Welfare reform and recession: past labour market responses to job losses and the potential impact of Employment Support Allowance

1999). Over the longer-term, these increases in levels of sickness benefit claims have proved to be a persistent problem in many former industrial areas.

The number of working-age recipients of Incapacity Benefit more than doubled from 1.2 million in 1984 to 2.5 million by 1997, and reached 2.8 million in 2003 (DWP benefits data). This continued an upward trend which began in the $1970 \mathrm{~s}$ and accelerated through the 1980s and much of the 1990s (Beatty, et al., 2009: $11)^{1}$.

This trend was the result of interactions between different parts of the benefit system. The 'benefit shift' from unemployment to sickness benefits was driven by workers discouraged by declining manual job opportunities, and by financial differentials in the social security system, which compensated sickness more generously than unemployment (Bell and Smith, 2004; Fothergill, 2001; Turok and Edge, 1999). The result in depressed labour markets was to favour being on sickness, rather than unemployment, benefits (Webster, 2006: 111). In weak labour markets the low-wages in entry-level jobs also acted as incentives to claim, and disincentives to leave, sickness benefits (Gregg and Wadsworth, 2000: 517518). ${ }^{2}$ It is also known that those with health-limitations face disadvantage in competing with other groups in the labour market, even when controlling for other factors (Berthoud and Blekesaune, 2006).

Beatty and Fothergill (2005) assert that the great majority of people are not claiming benefits fraudulently in any sense, but that the qualification test for IB, based on the ability to undertake certain physical tasks rather than to do any form of work, meant that many who could have worked were classified as permanently sick.

It has therefore been argued that Britain's official unemployment measures seriously underestimate the real level of unemployment in areas of labour market disadvantage. Beatty et al. (1996; 2005) developed the concept of 'hidden unemployment' to help understand this. They argue that, while individuals on IB have genuine health problems, many could nevertheless have been in employment in a more buoyant labour market. The most recent estimate they provide for this is 1 million 'hidden unemployed' on IB across Great Britain in 2006 (Beatty, et al., 2007: 22).

More recent work has explored the rising number of women claiming Incapacity Benefit, the geography of which is almost identical to that of men (Beatty, et al, 2009). This study suggested that 'hidden unemployment', those who could be expected to have been in employment in a 'genuinely fully employed economy', was again the main explanation of high IB claimant rates for women (Beatty, et al., 2009: 70-71). This work also shows that labour markets are becoming less gendered, with men and women in more direct competition for jobs, although this is happening relatively slowly, and unevenly across occupations and sectors (ibid: 36).

\section{Supply and demand side policy}

The appropriate balance between supply and demand based policies in areas of high non-employment has been the focus of much academic debate in recent years (examples include Campbell, 2000; Webster, 2000, 2006; Green and Owen, 1998; Peck and Theodore, 2000; Wilson, 2003). However in the UK, government-led employment expansion through means of expansionary macroeconomic management and regional policy has slipped almost entirely from the policy agenda, with thinking now firmly rooted in supply-side responses to enhance 'employability' 
p. 174. Welfare reform and recession: past labour market responses to job losses and the potential impact of Employment Support Allowance

through 'flexibility'. For Turok and Edge (1999; viii) policy makers appear to have decided "either that they cannot influence where jobs get created or that uneven development for labour does not really matter because people will respond through outward migration, wage moderation or retraining'. Debate has therefore focused on barriers to employment rather than on lack of jobs. Some barriers to work are presented as 'structural difficulties' in matching jobseekers to vacancies. These can include poor transport links, the housing market and the fixed costs of taking up employment (Bryson and McKay, 1994: 8). While others cite the importance of 'attitudinal barriers', suggesting the greatest obstacle that the unemployed face are their own attitudes towards work, often emphasising the belief that problems of labour market disadvantage lie in the " "preparedness" of those out of work to accept "flexible jobs" ' (ibid; 8; Peck and Theodore, 2000: 455-456; Peck, 2001: 6).

The increasing emphasis on flexibility in recent years has informed a significant overhaul of UK public welfare policy. Drawing particularly on US Workfare experiments, the welfare-to-work agenda has represented a 'paradigm shift' in public welfare (Peck and Theodore, 2001: 450; Martin, 2000: 469; Daguerre, 2004: 42). The centrepiece of these reforms has been the establishment of the Jobseekers Allowance (JSA) and the roll out of the New Deals. This has now been followed-up by extending the agenda to some inactive groups through the establishment of ESA, and through reforms to lone parent obligations.

The present supply-side focus though neglects the widely varied geography of labour demand which is crucial in determining the success of any intervention. Supply-side measures are often most relevant, and stand the greatest chance of success, in areas where there is strong demand for labour, but have been found to be much less effective where more limited opportunities exist to turn an individual's enhanced employability into employment (Martin, 2000: 469).

Lack of demand for labour can be particularly pronounced in former industrial areas. For example, in their evaluation of the economy in the English and Welsh coalfields, Beatty et al. (2005) found that only around 60 per cent of the male jobs lost in the coal industry had been replaced by $2004 .^{3}$

\section{The introduction of the Employment Support Allowance}

The current economic downturn occurs at a time of rapid changes to the welfare and benefits systems. Changes which are aimed at moving from a passive to an active welfare state, and which have been introduced to help meet the Government's target aspirations of reaching a working-age employment rate of 80 per cent, and reducing the number of people on incapacity by one million, by 2015. An important element of these reforms has been the establishment of the Employment Support Allowance (ESA).

On 27 October 2008, ESA was introduced for new claimants to replace Incapacity Benefit and Income Support received on the grounds of incapacity. The changes were a response to the welfare reform Green Paper (DWP, 2006: 4), A new deal for welfare, which provided the criticism that 'almost nothing is expected of [incapacity] claimants - and little support is offered'. ESA will build on the approaches adopted by the New Deal for Disabled People and Pathways to Work (Pathways), which was piloted in 2003 and rolled-out from 2005. The introduction of ESA has involved a number of important changes to the previous incapacity regime including: 
p. 175. Welfare reform and recession: past labour market responses to job losses and the potential impact of Employment Support Allowance

- fewer claimants will be exempt from assessment under the Work Capability Assessment (WCA) than under the old Personal Capability Assessment (PCA) medical regime. The WCA will also be a more stringent test

- most claimants will be expected to be able to prepare for a return to work. The majority of claimants will be go into a Work-Related Activity Group, under which they will receive a Work-Related Activity component (of $£ 24.00$ a week) in addition to the basic allowance, as long as they comply with the requirements for work-related activity

- if those in the Work-Related Activity Group do not comply with the regime they may lose 50 per cent of their Work-Related Activity component.

The recent welfare reform Green Paper (DWP, 2008b), No one written off, outlined a number of proposals to further amend the ESA and Pathways regime. The subsequent White Paper (DWP, 2008c), Raising Expectations, provided further details about the scope of these proposed changes, building on recommendations made by Professor Paul Gregg (2008) in his review of conditionality, Realising Potential. These changes include:

- between 2009 and 2013 all existing IB claimants are to be reassessed using the WCA, and will become subject to the ESA regime

- there will be a maximum two-year interval between medical assessments

- there will be a requirement that claimants in the Work Related Activity Group undertake some work-related activity in addition to attending their Work Focused Interviews (WFIs) at Jobcentre Plus (JCP) or a Pathways provider.

It is estimated by DWP that 60,000 more people a year will fail the WCA than previously failed the PCA under IB (DWP, 2008a); this equates to around 10 per cent of the annual on-flow under the old IB regime. There is though some early evidence which suggests the figure may end-up to be much higher, with early figures reportedly showing that more than two-thirds of applicants for ESA are being rejected at the WCA stage (Barker, 2009).

\section{The growth (and decline) of incapacity claiming}

The IB rate in Britain has grown significantly over the last twenty years or so. In 1984 the number of working-age male IB claimants stood at 844,200, but by 2001 this had almost doubled, reaching 1,657,800. Since then, and towards the tail end of the long-period of economic growth experienced since the early 1990s recession, the number had begun to fall and was down to 1,479, 200 by 2008 (see Figure 1). Most of this fall has been the result of reduced on-flows. 
p. 176. Welfare reform and recession: past labour market responses to job losses and the potential impact of Employment Support Allowance

\section{Figure 1: Working-age IB/SDA claimants, Great Britain, 1984-2008}

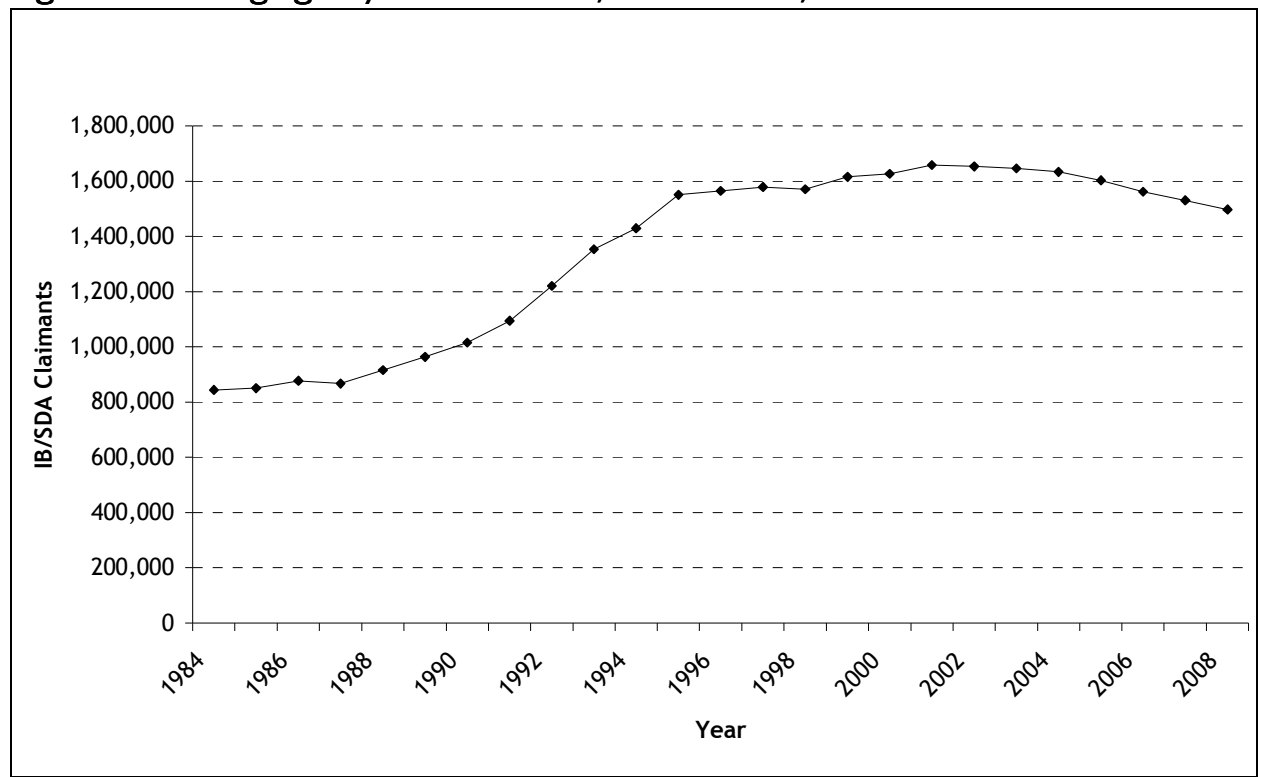

Source: DWP

Table 1 shows the recent fall in the IB rate, the proportion of the working-age population claiming IB, by area type since the national male IB claimant number peaked in 2001. All the area types recorded some reduction in their claiming levels, but this was most pronounced in the areas with the highest IB rates. This included a sizeable reduction of 3.1 percentage points in Industrial Hinterlands. There was also a significant drop of 2.2 percentage points in Regional Centres, which are large urban areas outside London. This reduction was driven largely by the relatively big declines in the claiming rates in some of the big former industrial cities like Glasgow, Liverpool and Newcastle. There were also relatively big declines in Centres with Industry (1.9 percentage points), again driven to some extent by the bigger cities, in this case Manchester and Birmingham, and there was also a sizeable decline across Manufacturing Towns (2.0 percentage points). These reductions are contrasted with the much smaller declines in more prosperous parts of the country, with reductions of less than one percentage point across London's Periphery and Suburb areas, and Prospering Small Towns, New and Growing Towns, and Prospering Southern England. However, overall claimant rates remained very much lower in these areas.

The reductions detailed in Table 1 began for the first time in more than 25 years to reverse some of the sustained and embedded labour market disadvantage in former industrial towns and cities. 
p. 177. Welfare reform and recession: past labour market responses to job losses and the potential impact of Employment Support Allowance

Table 1: IB rate change for working-age men by ONS area type: 2001-2008

\begin{tabular}{lccc}
\hline & $\begin{array}{c}\text { IB rate } \\
\text { May 2001 }\end{array}$ & $\begin{array}{c}\text { IB rate } \\
\text { May 2008 }\end{array}$ & $\begin{array}{c}\text { Percentage points change in } \\
\text { IB rate May 2001-2008 }\end{array}$ \\
\hline Industrial Hinterlands & 15.1 & 12.0 & -3.1 \\
Regional Centres & 11.8 & 9.6 & -2.2 \\
Centres with Industry & 11.8 & 9.9 & -1.9 \\
Manufacturing Towns & 11.5 & 9.5 & -2.0 \\
Coastal and Countryside & 9.6 & 8.5 & -1.1 \\
London Cosmopolitan & 9.5 & 8.1 & -1.4 \\
London Centre & 8.9 & 7.3 & -1.6 \\
London Suburbs & 6.9 & 6.3 & -0.5 \\
Prospering Smaller Towns & 6.4 & 5.6 & -0.8 \\
New and Growing Towns & 6.2 & 6.0 & -0.2 \\
Thriving London Periphery & 5.1 & 4.8 & -0.4 \\
Prospering Southern England & 3.7 & 3.6 & -0.1 \\
\hline
\end{tabular}

Sources: DWP, Census, Mid-Year Population Estimates

\section{The geography of unemployment in the recession}

Attention is now turned to the geography of unemployment in the current recession. The figures presented here draw on claimant count data. The claimant count is the number of people claiming unemployment-related benefits, primarily this is Jobseekers Allowance (JSA), but it also includes some people who don't qualify for JSA payments and receive only National Insurance Credits for being unemployed.

Unemployment can also be measured using the broader International Labor Organisation (ILO) definition which counts anyone who is out of work, is available to start work in the next two weeks, and, has looked for work in the last four weeks. This includes groups who are ineligible for, or chose not to claim, Jobseeker's Allowance. There are therefore differences between the ILO and the claimant count measures of unemployment. These differences are known to affect women to a greater degree than men, and also to generally reduce in scope during times of recession (ONS, 2002).

There are nevertheless several strengths of claimant count data. The figures are not based on a survey sample and so are highly reliable, they are the most up-todate measure of unemployment, and they provide accurate information for small areas like local authority districts and wards. As the data used to produce the ONS group definitions are at Local Authority level, use of the ILO definition drawing on the Annual Population Survey would be subject to a significant degree of error. The use of the claimant count also enables the most recent data to be produced, something of great importance at a time of rapid labour market change. For these reasons unemployment using the claimant count is reported here.

Some notable trends can be seen between the IB figures for 2001-8 presented in Table 1, and the impacts in 2008-9 of the recession, measured by the change in the proportion of the male working-age population claiming unemployment benefit 
p. 178. Welfare reform and recession: past labour market responses to job losses and the potential impact of Employment Support Allowance

shown in Table 2. What is immediately apparent is the relatively strong growth in the claimant count across all areas, increasing by two percentage points or more in all area types apart from Central London. However unemployment is growing most quickly in those areas with high rates of IB claiming, primarily old industrial areas. The biggest proportionate increase was across the Industrial Hinterland and Manufacturing Town area types (growing by 3.7 and 3.6 percentage points respectively). There were also strong increases across Centres with Industry (3.5 percentage points), and perhaps less expectedly, among New and Growing Towns (3.3 percentage points). This contrasts with increases below 2.2 percentage points across London areas, and a 2.0 percentage points increase in Prospering Southern England.

Table 2: Rate of claimant unemployment for working-age men by ONS area type: April 2009, and change, April 2008 - April 2009

\begin{tabular}{lcc}
\hline & $\begin{array}{c}\text { Claimant Count } \\
\text { April 2009 }\end{array}$ & $\begin{array}{c}\text { Percentage points change in the } \\
\text { Claimant Count - April 2008-2009 }\end{array}$ \\
\hline Manufacturing Towns & 7.1 & 3.7 \\
Industrial Hinterlands & 8.0 & 3.6 \\
Centres with Industry & 8.6 & 3.5 \\
New and Growing Towns & 6.2 & 3.3 \\
Regional Centres & 6.6 & 2.8 \\
Prospering Smaller Towns & 4.3 & 2.5 \\
London Suburbs & 5.4 & 2.2 \\
Coastal and Countryside & 4.6 & 2.2 \\
Thriving London Periphery & 4.1 & 2.1 \\
London Cosmopolitan & 7.0 & 2.1 \\
Prospering Southern England & 3.1 & 2.0 \\
London Centre & 5.0 & 1.5 \\
\hline
\end{tabular}

Sources: DWP, Census, Mid-Year Population Estimates

The recent stronger increase in claimant unemployment in weaker labour markets is likely to be the result of two drivers. First, they appear to be being disproportionately hit by increased recession unemployment. This may be the result of a combination of their different industrial structures, for example their greater reliance on badly affected sectors like manufacturing, as well as their different employment structures, with more contingent employment, for example agency working. Secondly, the claimant count will have been further swelled by the early impacts of welfare reform of IB and also of Income Support (IS) for Lone Parents (claimants of which tend to be more heavily concentrated in such areas). The eligibility for IS as a lone parent has been progressively reduced. It previously lasted until the youngest child was 16; this was lowered to 12 in November 2008, and then to 10 in October 2009 (and will be reduced to seven in October 2010). These reforms have increased labour supply as more individuals actively look for work who under previous benefit regimes could have claimed inactive benefits. This creates greater competition in the labour market, which in the absence of increased demand can feed into rising claimant unemployment. The data do not as yet allow the exact causal effects of these factors to be disentangled and the relative strength of each to be described. 
p. 179. Welfare reform and recession: past labour market responses to job losses and the potential impact of Employment Support Allowance

Critically these trends mean that weaker labour markets will need greater employment growth relative to other area types to return to pre-recession employment levels; levels at which they were beginning to see a reduction in their IB stock numbers.

Recent regional employment projections by Cambridge Econometrics and the Institute for Employment Research (2008), and covering the period 2007-2017, suggested a much slower period of economic and employment growth for the national economy in the medium term. They suggest per annum employment growth nationally will be around 0.6 per cent over the period, with regional variations ranging from 0.3 in the North East to 0.9 in London. Based on these projections, and bearing in mind the depth of the recession and the very large rises in unemployment seen, some of the worst impacted local authority areas could take ten years, or in some cases even longer, to recover to pre-recession employment levels. This problem is likely to be particularly acute in many former industrial areas which began with weaker labour markets, have suffered steeper rises in unemployment, and are largely in the regions predicted to grow the least.

The weakest labour markets will therefore face high and sustained levels of unemployment which will threaten the potential impact of ESA in tackling long-term worklessness.

\section{What difference will ESA make?}

The introduction of ESA should reduce the almost complete detachment from the labour market which occurred among many former industrial workers across old industrial areas in previous periods of recession. It should hold those becoming inactive due to ill-health closer to the labour market through regular contact with Jobcentre Plus which was not the norm under the previous IB regime. But the recession does raise an important question about how those with health limitations (including IB stock claimants) can now compete for jobs with newly unemployed groups. Furthermore it is probable that the employment needs of the claimant unemployed, who will receive more intensive forms of support under the new Flexible New Deal programme, and who represent a more politically sensitive measure of labour market disadvantage, will be prioritised over those on inactive benefits. A recent example of this is the establishment of the Future Jobs Fund which is funding of around $£ 1$ billion to support the creation of jobs primarily for long-term unemployed young people (aged 18-24).

The data on inactivity from previous recessions show the very long recovery period in some areas to loss of jobs. This recession is likely to cause higher, rather than hidden unemployment, and with a distinct geography - worst and longest in the weakest labour markets. There is a need to create jobs in these areas not just to alleviate the current unemployment impacts but also to provide the employment opportunities for stock IB customers who will be moved onto ESA between 2009 and 2013, and who may otherwise simply find themselves at the back of the jobs queue.

The success of the ESA policy therefore depends heavily on faster employment growth than previously experienced or currently predicted. As Fothergill and Wilson (2007), writing prior to the recent job losses, have highlighted, in the absence of strong employment creation, particularly in the North, Scotland and Wales, reforms to sickness benefits alone are unlikely to enable government targets to be met. 
p. 180. Welfare reform and recession: past labour market responses to job losses and the potential impact of Employment Support Allowance

This raises important questions about the government role with regards to the possibilities of developing demand-side policies to effectively complement supplyside interventions.

\section{Conclusions}

This paper has discussed the labour market adjustments which occurred previously in response to reduced demand for labour in Britain's old industrial areas, describing how the most significant adjustment has been through increasing levels of economic inactivity, particularly supported through rising incidence of Incapacity claims. Male IB claimant numbers grew rapidly during the 1980 s and 1990 s, with working-age claimant numbers rising from 844,200 in 1984 to 1,657,800 in 2001. Female working-age claimant numbers also rose steeply over this period, increasing from 355,400 in 1984 to a peak of $1,128,000$ in 2004 . These rises for men and women were heavily concentrated in old industrial areas. It has also been shown that male IB rates had begun to decline since 2001, in the later period of the long economic boom, and that this decline was most noticeable in the high IB claims areas.

The likely impacts which the reform of the sickness benefits system will have on future labour market adjustments were then considered. The argument which has been advanced is that unlike during previous periods of weakened demand for labour, recent welfare reforms mean that job losses are likely to feed more fully into increasing incidence of claimant unemployment. The emerging evidence presented here shows that so far, while claimant unemployment has risen across the board, the biggest proportional increases have been in industrial area types, which are concentrated in areas across the North of England, parts of Scotland and South Wales. This suggests that high unemployment is likely to be most concentrated in those areas beginning with the weakest labour markets, and these areas are likely to experience relatively long periods of high unemployment. This throws considerable doubt on the ability of ESA to continue the trend which had begun in recent years, and to reduce numbers of sickness benefit claimants to anything like the number the government has committed to. Although if, as one early report suggests, medical failure rates prove to be much higher under the new ESA system than under the IB regime, and much higher than predicted, there may be some degree of reversal of the benefit shift, with individuals moving from IB/ESA and onto Jobseekers Allowance.

This suggests the need to consider more fully the possibilities of demand-side interventions in the weakest labour markets. While demand-side policies have never been activated in response to high levels of inactivity, or "hidden unemployment', the political sensitivity of the claimant unemployment measure, which is likely to be high for a prolonged period, may mean such policies are given more serious consideration. This would have the potential to benefit both unemployed and inactive groups.

\section{Acknowledgements}

Many thanks to Peter Wood for commenting on an earlier draft. Thanks also to the anonymous referee for their useful suggestions. 
p. 181. Welfare reform and recession: past labour market responses to job losses and the potential impact of Employment Support Allowance

\section{Notes}

1 Similar, though often less pronounced, increases have been observed in other advanced economies (see Kemp, 2006).

2 This is less true since the establishment of Working Tax Credits.

3 There is of course a degree of diversity within this, with some of the smaller areas in Leicestershire and Warwickshire 'well on the way to full recovery', while others have made much slower progress (Beatty, et al., 2005: 2).

* Correspondence Address: Paul Sissons, Institute for Employment Studies, Sovereign House, Church Street, Brighton, BN1 1UJ, UK. Email: paul.sissons@employment-studies.co.uk.

\section{Bibliography}

Barker, B. (2009) New blow to sickness benefit applicants. Financial Times, 12 July.

Beatty, C. and Fothergill, S. (1996) Labour market adjustment in areas of chronic industrial decline: The case of the UK coalfields. Regional Studies, 30, 7, 627640.

Beatty, C. and Fothergill, S. (2005) The diversion from 'unemployment' to 'sickness' across British regions and districts. Regional Studies, 39, 7, 837-854.

Beatty, C., Fothergill, S. and Powell, R. (2005) Twenty years on: Has the economy of the coalfields recovered? Sheffield: CRESR, Sheffield Hallam University.

Beatty, C., Fothergill, S., Gore, T. and Powell, R. (2007) The real level of unemployment 2007. Sheffield: CRESR, Sheffield Hallam University.

Beatty, C., Fothergill, S., Houston, D., Powell, R. and Sissons, P. (2009) Women on Incapacity Benefits: A Statistical Overview. Project Working Paper, available at (http://www.geographyandgender.org/publications).

Bell, B. and Smith, J. (2004) Health, Disability Insurance and Labour Force Participation, Working Paper 218. London: Bank of England.

Berthoud, R. and Blekesaune, M. (2006) Persistent Employment Disadvantage, 1974 to 2003, ISER Working Paper 2006-9.

Bryson, A. and McKay, S. (eds) (1994) Is it worth working? Factors affecting labour supply. London: Policy Studies Institute.

Campbell, M. (2000) Reconnecting the long term unemployed to labour market opportunity: The case for a 'local active labour market policy. Regional Studies, 34, 7, 655-668.

Department for Work and Pensions (2006) A new deal for welfare: Empowering people to work, $\mathrm{Cm}$ 6730. London: HMSO.

Department for Work and Pensions (2008a) Impact Assessment of the Employment and Support Allowance Regulations $2008 . \quad$ HMSO: London (http://dwp.gov.uk/resourcecentre/ImpactAssessment180308.pdf)

Department for Work and Pensions (2008b) No one written off: reforming welfare to reward responsibility, $\mathrm{Cm}$ 7363. London: TSO.

Department for Work and Pensions (2008c) Raising expectations and increasing support: reforming welfare for the future, Cm 7506. London: TSO.

Fieldhouse, E. and Hollywood, E. (1999) Life after mining: Hidden unemployment and changing patterns of economic activity amongst miners in England and Wales, 1981-1991 Work, Employment and Society, 13, 3, 483-502. 
p. 182. Welfare reform and recession: past labour market responses to job losses and the potential impact of Employment Support Allowance

Fothergill, S. (2001) The True Scale of the Regional Problem in the UK. Regional Studies, 35, 3, 241-246.

Green, A. and Owen, D. (1998) Where are the jobless? Changing unemployment and non-employment in cities and regions. Bristol: The Policy Press.

Gregg, P. (2008) Realising potential: A vision for personalised conditionality and support. London: TSO.

Kemp, P. (2006) Comparing trends in disability benefit receipt, in: Kemp, P., Sunden, A. and Bakker Tauritz, B. Sick Societies? Trends in disability benefits in post-industrial welfare states. International Social Security Association.

Martin, R. (2000) Local labour markets: Their nature, performance, and regulation The Oxford Handbook of Economic Geography. Oxford: Oxford University Press, 455-476.

McKay, R. (1999) Work and nonwork: a more difficult labour market, Environment and Planning $A$, Vol. 31

ONS (2002) Measuring Unemployment (http://www.statistics.gov.uk/CCl/ nugget.asp?ID=165)

ONS (2009) The impact of the recession on the labour market (http://www.statistics.gov.uk/downloads/theme_labour/Impact-of-recessionon-LM.pdf)

Peck, J. (2001) Workfare States. New York: Guildford Press.

Peck, J. and Theodore, N. (2000) Beyond 'employability.' Cambridge Journal of Economics, 24, 729-749.

Peck, J. and Theodore, N. (2001) Exporting workfare/importing welfare-to-work: exploring the politics of Third Way policy transfer'. Political Geography, 20, 427-460.

Turok, I. and Edge, N. (1999) The jobs gap in Britain's cities: Employment loss and labour market consequences. Bristol: The Policy Press.

Warwick Institute for Employment Research/ Cambridge Econometrics (2008) Working Futures 2007-2017. (http://www.ukces.org.uk/pdf/Working\% 20Futures\%204\%20FINAL\%20090220.pdf).

Webster, D. (2000) The geographical concentration of labour market disadvantage. Oxford Review of Economic Policy, 16, 1, 114-128.

Webster, D. (2006) Welfare reform: Facing up to the geography of worklessness. Local Economy, 21, 2, 107-116.

Wilson, W. (1997) When Work Disappears: The world of the new urban poor. New York: Vintage Books. 